\title{
A bibliometric-based evaluation on environmental research in the Arab world
}

\author{
SH. H. Zyoud ${ }^{1}$ - D. Fuchs-Hanusch ${ }^{1}$ S. H. Zyoud ${ }^{2,3,4}$ • A. E. Al-Rawajfeh ${ }^{5,6}$ • \\ H. Q. Shaheen ${ }^{7}$
}

Received: 17 May 2016/Revised: 2 October 2016/Accepted: 9 November 2016/Published online: 26 November 2016

(c) The Author(s) 2016. This article is published with open access at Springerlink.com

\begin{abstract}
The Arab world's environment is among the most vulnerable and harsh ones across the globe. This entails much efforts to mitigate the potential environmental risks. Analysing contributions of Arab scholars in environmental research in terms of quantity and quality can bring up insights on their endeavours in this regard. Bibliometric techniques are proposed to conduct such this analysis over publications originated from Arab world in a leading environmental journal "Science of the Total Environment". Research productivity is being used as quantitative indicator, while citation rates and Hirsch index $(h$-index) are being used as qualitative indicators. The
\end{abstract}

Editorial responsibility: Tan Yigitcanlar.

SH. H. Zyoud

shaherzyouds@gmail.com

1 Institute of Urban Water Management and Landscape Water Engineering, Graz University of Technology, Stremayrgasse 10/I, 8010 Graz, Austria

2 Poison Control and Drug Information Center (PCDIC), College of Medicine and Health Sciences, An-Najah National University, Nablus, Palestine

3 Department of Clinical and Community Pharmacy, College of Medicine and Health Sciences, An-Najah National University, Nablus, Palestine

4 WHO Collaborating Centre for Drug Information, National Poison Centre, Universiti Sains Malaysia (USM), Gelugor, Penang, Malaysia

5 Chemical Engineering Department, University of Jordan, Amman, Jordan

6 Chemical Engineering Department, Tafila Technical University, Tafila, Jordan

7 Civil Engineering Department, An-Najah National University, Nablus, Palestine research outputs were compared with those obtained from non-Arab Middle Eastern countries (Iran, Turkey and Israel). Worldwide research productivity was 17,258 documents, while that from Arab countries, Iran, Turkey and Israel were $215,34,83$ and 87 documents, respectively. The $h$-index of Arab world research was 31 , and total citations were 3616 with an average of 16.8. The highest share of publications was recorded by Saudi Arabia (53 documents; 24.7\%). Egypt and Saudi Arabia had highest $h$ index with 15 for each one. American University of Beirut in Lebanon was the highest productive institution (16; $7.4 \%)$. The most collaborated country with Arab world was France $(29 ; 13.5 \%)$. In the conclusion, the study reveals a clear gap in terms of research productivity between Arab countries and other Middle Eastern countries, precisely Israel and Turkey. More research efforts through optimizing investments in environmental research, developing regional experiences and fostering international collaboration are required to eliminate these lags.

Keywords Benchmarking - Comparative analysis . Scopus $\cdot$ Total environment

\section{Introduction}

Human beings were able for thousands of years to be engaged in inventive transformations of humanized environments by symbiosis or creative partnership with nature (Dubos 1976). A great acceleration and intensification in this process has been witnessed since the nineteenth century. These human activities have grown increasingly with significant deterioration of environment as a consequence (Cocârţă et al. 2016). As a result to these challenges, concerns for the long-term consequences of human 
interventions into environment and strict ecological constraints that conform with human nature should manage the scientific technologies and industry (Dubos 1976). This will contribute in mitigating the stresses on the environment and sustaining the human well-being which based on the integrity of economic, sociopolitical and environmental conditions (Holdren 2008).

Recent years have witnessed increased interests by researchers in the environmental research, which is clearly evident by the dramatic rise in the volume of scientific output in this field of research. It is being one of the most discussed topics among both physical and social scientists (Ahmed et al. 2015). This is accompanied by recognition of the fact that environmental degradation is a threat to human societies, and the environmental problems are being to attract much more attention by policy makers, public and media. Additionally, these problems have featured hugely in scientific publications and warnings (Tolba and Saab 2009). Such problems that have been hugely addressed in the literature include, as an examples, air pollution (Ahmadi et al. 2015; Li et al. 2016a), climatic changes (Carleton and Hsiang 2016; Deutsch et al. 2015), industrial effluents (Padmanaban et al. 2016), desertification (Juřička et al. 2016; Li et al. 2016b), vulnerability of groundwater to external pollutants (Damak et al. 2016; Iqbal et al. 2014), land degradation (Akhtar-Schuster et al. 2016; Kosmas et al. 2016) and aquatic environment pollution with organic and inorganic pollutants (Shakeri et al. 2015).

In many of developing countries, the environmental degradation cost is evaluated as $4-8 \%$ of the gross domestic product (GDP) (World Bank 2001). In case of Arab world, the environmental degradation cost is estimated to be at 5\% of GDP (Tolba and Saab 2009). The damage cost to the global environment in Middle East and North Africa (MENA), of which Arab countries are the majority, is estimated at $0.5-1.6$ of the GDP with estimated mean of $0.9 \%$ of GDP (Ahmed Hussein 2008). This figure is 1.5 times higher than figures in high-income countries (Ahmed Hussein 2008), which in conclusion leads to the confirmation that Arab world countries are among the severe affected nations globally by environmental problems.

The Arab world is extending from the Atlantic Ocean to the Indian Ocean and from sub-Saharan Africa to the Black and Caspian Seas. It was the home of 359 million people in 2010 and projected to reach nearly 600 million in 2050 (Mirkin 2010). This region is located within a zone characterized by its high vulnerability to climate change effects and diagnosed to be the nearest as a direct victim of climate change (Elasha 2010). Its people for thousands of years were able to deal effectively with the risks of climate change by adapting their strategies of survival to variations in temperatures and rainfalls (Verner 2012).
The demanding and harsh environment of this region, which recognized by its location in a hyper-arid to arid zone, water scarcity, very low and variable precipitation, extreme events of desertification and droughts combined with high levels of poverty (Verner 2012), air pollution, inappropriate capacity planning for waste management and degradation of coastal and marine environment, boost the risks of its vulnerability to climate change effects and environmental challenges (Tolba and Saab 2009). These impacts threaten to counter the gains of this region that have been achieved over the past few decades in human and economic developments (El-Zein et al. 2014; The World Bank 2010).

The realization of the inevitability of placing the environmental issues as topmost priorities to guarantee the sustaining of economic growth and social developments in the Arab world should boost the efforts of addressing and mitigating the environmental risks. Since the economic growth, social well-being and regional competitiveness, at long terms, are attached with advances in science and technology (Durant et al. 1989; Minguillo et al. 2014), the scientific research output of a country and/or a region can be deemed as a most relevant indicator of these advances linked with economic growth (Ntuli et al. 2015). The examination of evolution of scientific research, in terms of quantity and quality, can help in assessing the endeavours of a country or a region towards meeting the targets of sustainable development. Therefore, a large amount of studies are devoted to evaluate science and technology performance within a given discipline or body of the literature at national, regional or global levels (Yataganbaba and Kurtbaş 2016). Consequently, the research statement is concerned with the evaluation of Arab world's commitments to the state of science in fields of research related to environmental realm and its contribution to the global literature in this vital topic by conducting a quantitative and qualitative assessment of its research output in this field. It is a crucial task to properly understanding the current status of research and to identify the existing research directions in this field in order to assist in future research investments, to improve research activities, and it will be of advantage for researchers and practitioners to conduct and identify new lines of environmental scientific research.

A general overview on research productivity in Arab world shows an increase from $0.6 \%$ of total global research productivity in 1981 to $0.9 \%$ in 2000 (UNESCO Institute for Statistics 2005). This increase in the scientific productivity has been accompanied by improvements in educational levels, health services and developments in living norms during the last periods in the majority of Arab countries (Benamer and Bakoush 2009). Since the region had a successful historical role in the scientific renaissance as well as a proud history of science and knowledge 
(Maziak 2005), the neglect of science is potentially starting to fade away with strong hopes to restore the balance based on grassroots initiatives (Masood 2002).

One of the most widely used and accepted tools to measure the scientific research productivity in any particular filed of research is bibliometric analysis. This technique utilizes statistical indices and quantitative analyses to assess institutions, individuals and/or countries in terms of their research output (Wallin 2005). It is also useful in making pronouncements related to qualitative features of scientific research output (Wallin 2005). This technique is valuable in deriving good information and knowledge about the status of scientific research activities in specific disciplines that help researchers to recognize novel schemes among research (De Battisti and Salini 2013). Furthermore, it is a well-recognized technique for conducting systematic analyses (van Raan 2005). This kind of research is common in different disciplines such as in industrial and pharmaceutical wastewater research (Zyoud et al. 2016a, b), medicine (Zyoud et al. 2015a), hospitality management (García-Lillo et al. 2016), clinical research (Jain et al. 2015), membrane science (Fu and Ho 2015), quality of water (Hu et al. 2010), desalination research (Zyoud and Fuchs-Hanusch 2016) and toxicology research (Zyoud et al. 2014).

With an aim of assessing the research output of Arab world in environmental research, their contributions in a leading environmental journal, "Science of the Total Environment", have been examined as a case study by employing bibliometric techniques. This assessment will examine the published research originated from Arab world in terms of: evolution of growth rates, quality of research, collaboration figures, productivity of countries, institutes and authors, and prevalent topics with major concerns. Furthermore, the outputs of this assessment will be compared with that of other non-Arab Middle Eastern countries which are facing nearly the same environmental risks. The examined journal, "Science of the Total Environment", was launched in 1972 by Eric Hamilton, the founding editor of the journal. It is an influential journal in its fields of research and is a truly global journal (Nriagu 2008). As the environmental pollution issues became serious in many of developing countries, researchers from these regions found in Science of the Total Environment journal a venue of choice to publish their studies and consequently the published research from these regions have significantly increased (Nriagu 2008). The "Science of the Total Environment" journal is a fully peer-reviewed and an international journal which is concerned in publishing original research on the total environment that covers five fields: atmosphere; hydrosphere; biosphere; lithosphere and anthroposphere; and its relationship with humankind (Elsevier 2016).
By surveying the literature and up to the knowledge of authors, this work is the first of its kind in addressing bibliometric performance indicators which are related to environmental research activities originated from Arab world and have been published in a leading environmental journal. As it offers a representative perspective about the efforts of Arab scholars in addressing and tackling environmental issues with urgent concerns, it can be considered as an informative study which gives a structured insight over environmental research activities in a highly susceptible region to environmental changes and fluctuations.

\section{Materials and methods}

It is mostly common in conducting bibliometric analyses to use one out of four well-recognized and known databases and digital libraries that encompass Google Scholar, PubMed, Web of Knowledge and Scopus (Falagas et al. 2008). Among these databases, Scopus which is a service provided by Elsevier appears to be the library with individually the most comprehensive coverage (Hull et al. 2008) and indexes a number of journals much more than any other database of scientific research (Kulkarni et al. 2009). Furthermore, it grants the most flexible overview on the scientific research output at global levels in all of science's realms (Yataganbaba and Kurtbaş 2016).

For executing the present bibliometric analysis, Scopus database was used to extract the required data for this analysis. The search in Scopus was limited to "Science of the Total Environment" journal as a source of scientific research output. All subject areas in Scopus database which cover health, life, social and physical sciences are considered during the search. Additionally, the documents types (article, article in press, review) are taken into consideration with exclusion of all other types of documents such as letters, notes and editorials. The scientific research output beyond the year 2016 was excluded since the time interval after 31 December 2015 is yet open for incoming issues. The results of this search will provide the total research output that has been published in the examined journal at global level. To restrict the search for research output belongs to Arab world, all Arab countries under the umbrella of Arab League: Egypt; Algeria; Morocco; Libyan Arab Jamahiriya; Sudan; Mauritania; Tunisia; Djibouti; Saudi Arabia; Bahrain; Kuwait; United Arab Emirates; Comoros; Oman; Qatar; Yemen; Iraq; Jordan; Palestine; Lebanon; Syrian Arab Republic; and Somalia, are employed as country keys and affiliation countries in the advance search that offers by Scopus database during the defined time period. To fulfil the requirement of the proposed comparative analysis, the same methodology that has been followed in case of Arab world was adopted to 
retrieve the documents and extract the data related to research output of the three non-Arab Middle Eastern countries (Iran, Turkey and Israel).

The task of searching was applied one time (2 May 2016) to eliminate the bias that may arise as a result of continued updating of database of Scopus. Scopus database displays the research output in the form of list with 20-200 items per page, and it is possible to export the extracted documents into Excel spreadsheets. The results of the search can be revised by author name, document type, affiliation, title of the source, rates of publications/year and subject category. Within these results, it is possible to commence a new search and further analyses (Falagas et al. 2008). The resulted data will be analysed to build up an informative framework and perspective about: (a) tracing the evolution of scientific research output over the time, (b) patterns of research collaboration between different countries, (c) rates of citations of the published research, (d) journals that mostly cited the published research, (e) the most prevalent areas of interests, (f) the most cited articles and (g) the most prolific institutions and authors. The Arab countries will be sorted according to their research output based on standard competition ranking (SCR) formula and will be arranged in ascending order. The SCR will be also used to rank the top ten most prolific: affiliations, prevalent areas of interests, prolific authors and published documents that have attracted most citations.

As this analysis will offer different bibliometric indicators, these indicators are classified as quantitative indicators (i.e. research output) or qualitative ones (i.e. the citation rates and impact factors of journals). The Hirsch index ( $h$-index), which is an indicator that integrates measures of quantity (represented by the number of publications) and measures of quality (represented by the total citation scores) (Egghe 2006), will be used to demonstrate the total citations in which the published research has gained. This index is of benefit to identify the significance, importance, impact of the cumulative research of researchers (Hirsch 2005) and to characterize the research performance in qualitative view (Meho and Rogers 2008). To demonstrate its concept when it is applied to examine the impact and productivity of scientific research at country level, it is possible to state that: if a country attracted $h$ index with a value of 20 , this means that this country had published 20 documents, and at least, each document has gained 20 citations. With the aim of showing the impact factors (IF) of journals that have cited research published from Arab world, Journal Citation Reports (JCR): 2015 edition released by Thomson Reuters has been used.

A programme of statistical analysis, IBM $^{\circledR}$ SPSS $^{\circledR}$ statistics version 20 (IBM Corporation, Armonk, NY), has been employed to compute the descriptive statistics measurements that have been associated with research output from Arab world and non-Arab Middle Eastern countries. These statistics include the count frequency and percentage, median, interquartile range, mean and sum. The categorization of countries and regions across the world which will be examined in this analysis is based on classification of SCImago Journal \& Country Rank, which is a portal that includes the countries and journals scientific indicators promoted by the information contained in Scopus database (SJR 2016).

A content analysis of abstracts of published research from Arab world and non-Arab Middle Eastern countries is carried out to identify the most prevalent discussed topics. This analysis can recognize the emerging and current issues and others that no longer of significant interest (Anderson and Shattuck 2012; Armfield et al. 2014). To conduct this analysis, the abstracts of published research are exported to NVivo 10 (QSR International) programme. It is followed by a distribution analysis of word frequencies. The grouping of word frequencies was limited to search for terms with stemmed words as the results of this procedure were more flexible than the search for terms with exact matches. The length of the word during the search was fixed to three letters. Tag clouds are used to provide visual illustration. The size of each word ("tag") in the tag clouds will be in proportion with its occurrence frequency in the source.

\section{Results and discussion}

Numerous bibliometric studies in environmental sciences have been accomplished and were seeking to address the environmental research activities from bibliometric perspective. They have been conducted to identify the bibliometric indicators associated with research in environmental science at global levels (Dragos and Dragos 2013; Khan and Ho 2012), in a specific topic within environmental sciences (Fu et al. 2013), in a geographic area (Acosta et al. 2009) or at country level (Katz and Plevin 1998; Mamtora et al. 2013). The present study is a complementary work to the aforementioned studies and is inspired by the need to examine research activities concerned with environmental science in a region (i.e. the Arab world) which is subject to severe environmental risks.

The study identified 17,258 documents published at global level from 146 countries in Science of the Total Environment journal during the period from 1972 to the end of year 2015. The average of publications was 392 documents/year with a range from 23 to 1753 documents. The USA assumed the first position in the world ranking in the context of total published research with 2979 documents $(17.3 \%)$ and followed by UK $2130(12.3 \%)$. The total was 215 documents when the search was limited to 
publications from Arab world only. This figure equals $1.25 \%$ of total research productivity at global level. Among these documents, there was 214 documents $(99.5 \%)$ published as original journal articles and $1(0.5 \%)$ was a review article. Figure 1 illustrates the evolution of research productivity from Arab world in comparison with global research output. As it is noticed, the researchers from Arab world had begun their activities in 1982 and their productivity has grown very modestly with a noticeable peak in 1992. These activities are developed progressively in association with peaks and downs. The breakthrough was in the last four years where about $49.8 \%$ of the total output by Arab world has been taken place.

The present figure of $1.25 \%$ that demonstrates Arab world's contribution in the global research is to some extent compatible with Arab world's achievements in published research worldwide. The Arab world is contributed for a meagre of $1.4 \%$ of the scientific research papers published throughout the world (Boumedjout 2010). The present figure is better than of that of medical research originated from Arab world. The Arab world is currently contributing less than $0.5 \%$ of published papers appearing in 200 major medical journals (Maziak 2005). This finding has been also confirmed in other bibliometric studies that have been conducted over medical research at Arab world level (Sweileh et al. 2014, 2015). Otherwise, in some fields of research such desalination, the contribution of Arab world to global research was unique and valued about $16 \%$ (Zyoud and Fuchs-Hanusch 2016). This result was in line with their distinctive achievements in fields of research related to desalination (Masood 2002).
Table 1 listed Arab world countries along with their bibliometric indicators. The analysis of the list shows that three Arab countries (Comoros, Djibouti and Somalia) did not have any contribution towards research in Science of the Total Environment journal. Furthermore, it shows that research activities in some Arab countries were insufficient or even negligible and Arab world countries show different patterns in terms of productivity, collaboration with other countries and citation rates. The largest number of publications at Arab world level was from Saudi Arabia (53; 24\%.7), followed by Egypt (44; 20.5\%), Morocco (21; 9.8\%), Lebanon $(19 ; 8.8 \%)$, Tunisia $(16 ; 7.4 \%)$ and Kuwait $(14 ; 6.5 \%)$. At the time of analysing data (2 May 2016), published research from Arab world has gained 3616 citations. The median of citations (interquartile range) was 9.0 (4.0-18.0), and their average was 16.82 . The highest median (interquartile range) was registered for published documents from Syrian Arab Republic 25.0 (11.0-45.0), followed by 12.5 (1.0-31.25) for Sudan. The total retrieved documents attracted $h$-index of 31 which implies that at the time of gathering and analysing data, there were 31 documents which attracted at least 31 citations for each document. At country's level, the highest $h$-index was 15 and it was recorded by each of Saudi Arabia and Egypt, followed by 10 for Lebanon, 9 for Kuwait and 8 for each of Morocco and Tunisia. Egypt was the most collaborated country with other countries. It has collaborations with 24 countries and followed by Saudi Arabia with 23 countries.

The highest rate of contributions was from Saudi Arabia and Egypt, which was about $45 \%$ of the total Arab world's productivity. For Saudi Arabia which has massive oil
Fig. 1 No. of published documents at Arab world level in "Science of the Total Environment Journal" in comparison with research productivity from the global

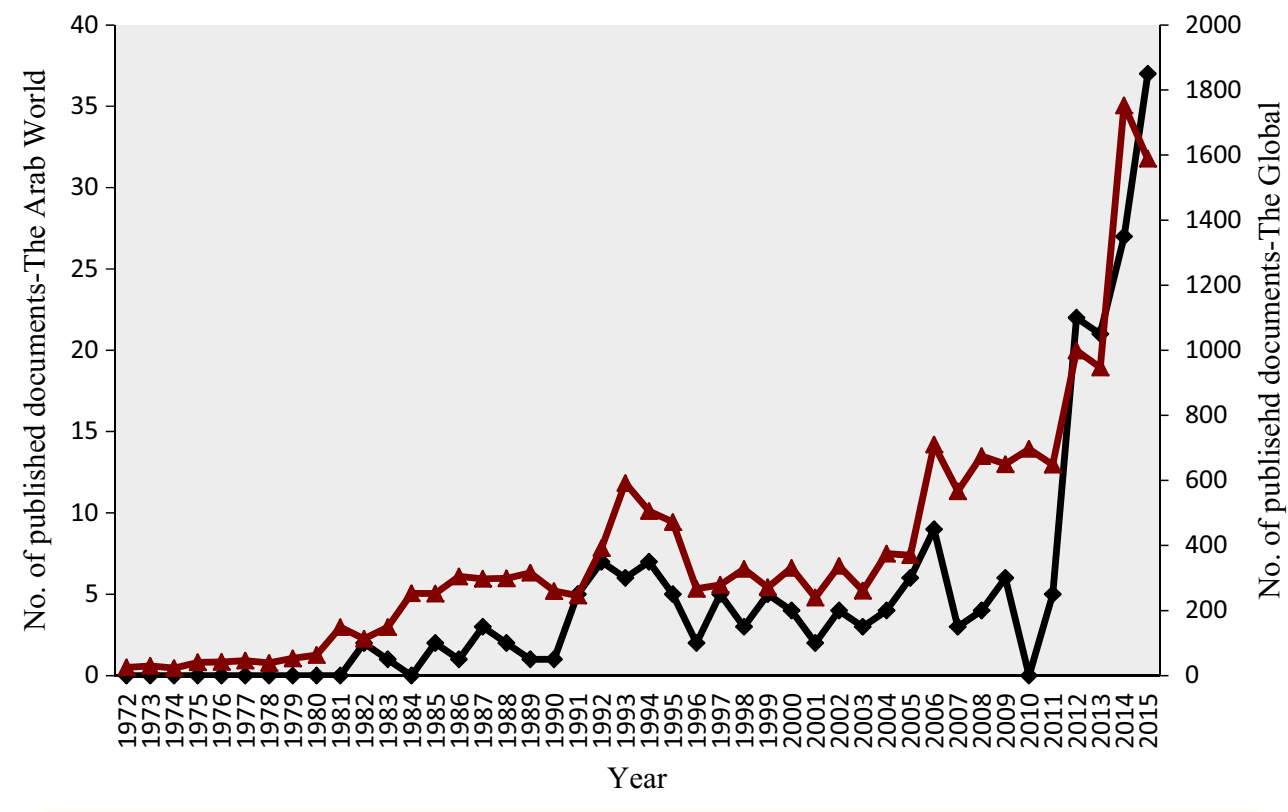

No. of published documents from the Arab world - No. of published documents from the Global 


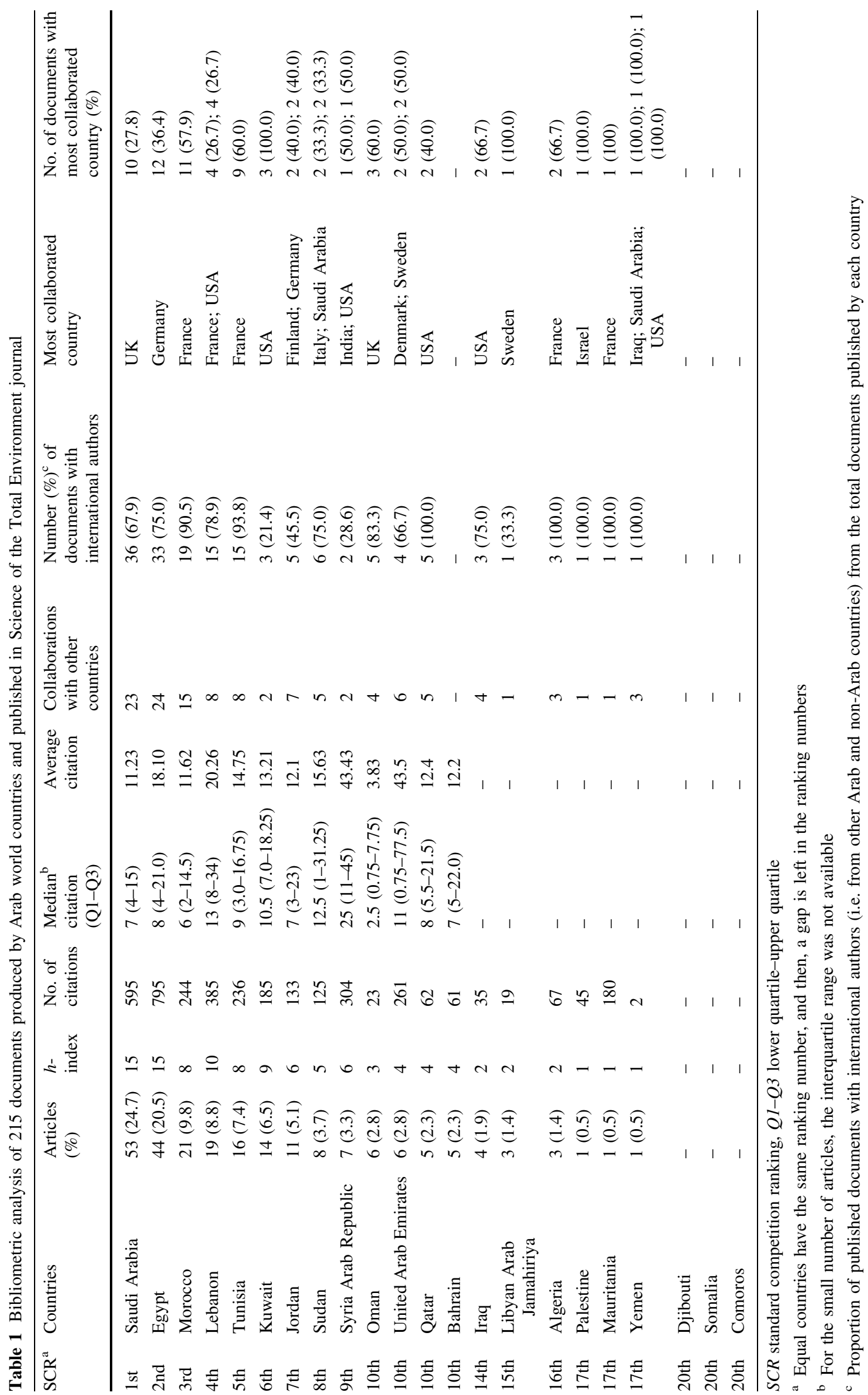


reserves and considered as the largest producer of crude oil, the predicted declining of oil production (Simmons 2006) associated with the rapid increase in population growth which rated as the highest in Arab world (3.24\% is the annual growth, while the average in Arab world is 2.37\%) (Onsman 2010) was the pillars to diversify its economy and to establish a world class science and technology sector through building technology incubators (Alshumaimri et al. 2010; Shin et al. 2011). This country is turning into a regional hub for advanced education and research and shifting its economy into knowledge-based one instead of oil-based one (Meo 2015; Shin et al. 2011).

The productivity of Saudi Arabia in Science of the Total Environment journal which was $0.31 \%$ of the total global publications is the same as its contribution in all fields of research at global level as pointed out in the database of SCImago Journal and Country Rank (SCImago 2016). Furthermore, its position in the list of countries that have contributions in this journal (41 out of 146) was nearly the same in the list of country ranking in all fields of research as it is ranked in the position 44 (SCImago 2016). Saudi Arabia showed high rates of collaboration with other countries. This finding may be an outcome of the fact that Saudi Arabia had bigger pool of international scholars than most other countries (Shin et al. 2011). Egypt was the second most collaborated country with Saudi Arabia and vice versa. This was a straight reflection of the strong research partnerships between the two countries where the joint research on annual bases has boosted tenfold during the last decade and is fast accelerating (Adams 2012).

The environmental challenges in Saudi Arabia are like those in other Arabian Gulf countries which have experienced a major increase in wealth resulted from oil industry and accompanied by swift urbanization. As pointed out by Yeatts et al. (2012), the scientific interests in environmental health research are for many factors including the rapid transformation in the physical environment associated with raises in industry and traffic-related pollutants, extremely high temperatures and alterations in lifestyles. They concluded that, despite the accelerated and dramatic environmental changes, the environmental health-related research was little (Yeatts et al. 2012). Similar to the previous finding, the global research report by Thomson Reuters indicated that during the period from 2005 to 2009, the region of the Middle East (Persian, Arabian and Turkish Middle East) published only 4676 documents in environment/ecology research which represent a proportion equal to $3.24 \%$ of total world's research productivity (Adams et al. 2011). The published research from Saudi Arabia showed much concerns on air pollution, public health, toxic materials effects, dispersion of hazardous materials, water pollution and water resources, industrial wastewaters and wastewaters, marine environmental and coastal zones, analysing ozone trends, solid waste and depletion of resources.

In case of Egypt, its population size is a pivotal factor that contributes in increasing its scientific research activities which rely on population size, socio-economic factors or overall scientific activity of any country (Miro et al. 2009). Furthermore, Egypt assumes the second position after South Africa in Africa continent in terms of scientific research productivity (Waast and Rossi 2010). The Egyptian environmental experts and scientists have played a significant role in producing regional and global discourses around environmental concerns such as desertification, water scarcity and conservation of nature (Sowers 2013). Most of articles within this study were applied for case studies in Egypt and were concerned with environmental challenges such as pollution of coastal waters by industrial wastewaters, sewage and leaching from solid waste disposal sites, hazardous pollutants interact in soils, air pollutants, water quality, pesticides effects on aquatic life, heavy and trace metals effects, and public health. Additionally, field and analytical studies that are based on collection of samples, measuring concentrations and levels of different pollutants were the predominance.

The collaboration patterns with researchers from nonArab countries, as shown in Table 2, demonstrated high levels of collaborations with researchers from Western Europe mainly France, followed by researchers from North America, mainly the USA. The present study identified 140 (65.0\%) published documents with 40 countries resulted from collaboration with non-Arab countries. The highest $h$ index (21) resulted from collaborations between researchers from Arab world and Western Europe. It was followed by $h$-index (10) as a result of collaborations with Northern America. Furthermore, the collaboration between Arab world and Western Europe produced the high rates of citations (1485), followed by the collaboration with Northern America which produced (491) citations. The high figures of collaboration between Arab scholars and their counterparts in Western Europe and Northern America can attributed to the fact that the majority of Arab researchers graduated from Europe and US universities, and many of the graduated researchers and students from Arab world have gained their education and training in environmental field of research from these two regions where the principles and concepts of environmental sustainability measures are being emphasized in research and science (Zyoud et al. 2015b).

France occupies the first position in Arab-non-Arab collaboration at countries' level. This is due to the active participation of Maghreb countries, mainly Morocco and Tunisia, and Lebanon in the research activities at Arab world level. Numerous studies affirmed that France is heavily engaged in research and associated with its former 
Table 2 Analysis of collaborations between Arab world countries and non-Arab countries

\begin{tabular}{|c|c|}
\hline Region/country ${ }^{\mathrm{a}}$ & No. of documents (\%) \\
\hline Western Europe & $104(48.4)^{\mathrm{b}}$ \\
\hline France & 29 (13.5) \\
\hline Spain & $22(10.2)$ \\
\hline Germany & $21(9.8)$ \\
\hline UK & $21(9.8)$ \\
\hline Italy & $11(5.1)$ \\
\hline Sweden & $8(3.7)$ \\
\hline Austria & $3(1.4)$ \\
\hline Finland & $3(1.4)$ \\
\hline Denmark & $3(1.4)$ \\
\hline Belgium & $2(1.0)$ \\
\hline Netherlands & $5(2.3)$ \\
\hline Portugal & $3(1.4)$ \\
\hline Greece & $3(1.4)$ \\
\hline Luxemburg & $1(0.5)$ \\
\hline Monaco & $1(0.5)$ \\
\hline Norway & $1(0.5)$ \\
\hline Cyprus & $1(0.5)$ \\
\hline North America & $31(14.4)^{\mathrm{b}}$ \\
\hline USA & $24(11.2)$ \\
\hline Canada & $8(3.7)$ \\
\hline Asiatic Region & $15(7.0)^{\mathrm{b}}$ \\
\hline India & $4(1.9)$ \\
\hline South Korea & $3(1.4)$ \\
\hline China & $3(1.4)$ \\
\hline Pakistan & $2(1.0)$ \\
\hline Japan & $1(0.5)$ \\
\hline Singapore & $1(0.5)$ \\
\hline Taiwan & $1(0.5)$ \\
\hline Viet Nam & $1(0.5)$ \\
\hline Latin America & $7(3.3)^{\mathrm{b}}$ \\
\hline Brazil & $2(1.0)$ \\
\hline Mexico & $2(1.0)$ \\
\hline Argentina & $1(0.5)$ \\
\hline Chile & $1(0.5)$ \\
\hline Costa Rica & $1(0.5)$ \\
\hline Pacific Region & $6(2.8)^{\mathrm{b}}$ \\
\hline Australia & $6(2.8)$ \\
\hline Eastern Europe & $3(1.4)^{\mathrm{b}}$ \\
\hline Bulgaria & $1(0.5)$ \\
\hline Croatia & $1(0.5)$ \\
\hline Serbia & $1(0.5)$ \\
\hline Slovenia & $1(0.5)$ \\
\hline Middle East & $3(1.4)^{\mathrm{b}}$ \\
\hline Israel & $2(1.0)$ \\
\hline Turkey & $1(0.5)$ \\
\hline Africa Region & $1(0.5)^{\mathrm{b}}$ \\
\hline Madagascar & $1(0.5)$ \\
\hline
\end{tabular}

Table 2 continued

\begin{tabular}{lc}
\hline Region/country $^{\mathrm{a}}$ & No. of documents $(\%)$ \\
\hline Arab-Arab & $18(8.4)^{\mathrm{b}}$ \\
Arab-Arab & $18(8.4)^{\mathrm{b}}$ \\
\hline a The study recognized $140(65.0 \%)$ & documents with 40 countries as \\
a result of collaborations between & Arab countries and non-Arab \\
countries & \\
b The total surpasses $65.0 \%$ as a result of data overlapping due to \\
multi-country collaborations
\end{tabular}

colonies in research collaborations (Harford 2015; Nature 2015). The USA was in the second position in terms of collaboration with Arab world. As the most contributor in scientific research at global level, USA sustains to be a major contributor in the scientific collaborations (Gazni et al. 2012). Germany and UK were also among the top collaborators in research with Arab world. They are frequent partners with this region and their substantial power for collaborative research partnerships at international levels and the quality of their domestic research are major attractive factors in collaboration with them (Adams et al. 2011). The international collaboration has a powerful in producing higher-impact science research through complementary expertise (Havemann et al. 2006), and it is of benefit in reducing the costs, minimizing the duplication of skills and equipment that are required in research (Toope et al. 2012) and boosting the efficiency (Plucknett and Smith 1984).

The list of top ten cited documents in Science of the Total Environment journal is displayed in Table 3. The overwhelming majority of documents in the list of most cited documents were articles except one document which was a review article (Al-Yousuf et al. 2000; Baveye et al. 1999; El-Fadel and Massoud 2000; Elminir 2005; Khan et al. 2011; Louiz et al. 2008; Loutfy et al. 2006; Nawar and Doma 1989; Qadir and Oster 2004; Rocher et al. 2004; Romeo et al. 1999). The citation rates for these documents range from 57 to 202. Even one review article was found in this list; it was the only one that appeared in total research published by Arab world in the examined journal. This finding affirms the need to increase the focus of conducting review articles which are of multi benefits such as assessing in identifying the current state of research, identifying the experts in the field, the used methodologies and the discussed issues in past studies, and from scientific point view, review articles are part and parcel of good science (Shanbhag 2016).

Table 4 lists the top ten most prolific universities and institutions in Arab world. The most prolific university was American University of Beirut, Lebanon (16; 7.4\%). It was followed, respectively, by King Abdulaziz University, Saudi Arabia (15; 7.0\%), and King Saud University, Saudi 
Table 3 Ranking of top ten cited documents published by researchers with affiliations to institutions in Arab world in Science of the Total Environment journal

\begin{tabular}{|c|c|c|c|c|}
\hline $\mathrm{SCR}^{\mathrm{a}}$ & $\begin{array}{l}\text { Name of authors and } \\
\text { year of publication }\end{array}$ & Title & $\begin{array}{l}\text { Type of } \\
\text { document }\end{array}$ & $\begin{array}{l}\text { Times } \\
\text { cited }\end{array}$ \\
\hline 1 st & Al-Yousuf et al. (2000) & $\begin{array}{l}\text { Trace metals in liver, skin and muscle of Lethrinus lentjan fish species in relation to } \\
\text { body length and sex }\end{array}$ & Article & 202 \\
\hline 2nd & Romeo et al. (1999) & Heavy metal distribution in different fish species from the Mauritania coast & Article & 180 \\
\hline $3 \mathrm{rd}$ & Qadir and Oster (2004) & $\begin{array}{l}\text { Crop and irrigation management strategies for saline-sodic soils and waters aimed at } \\
\text { environmentally sustainable agriculture }\end{array}$ & Review & 171 \\
\hline 4th & Nawar and Doma (1989) & Removal of dyes from effluents using low-cost agricultural by-products & Article & 125 \\
\hline 5 th & Elminir (2005) & Dependence of urban air pollutants on meteorology & Article & 114 \\
\hline 6th & Khan et al. (2011) & $\begin{array}{l}\text { Exploration of } \mathrm{CeO}_{2} \text { nanoparticles as a chemi-sensor and photo-catalyst for } \\
\text { environmental applications }\end{array}$ & Article & 63 \\
\hline 7 th & $\begin{array}{l}\text { El-Fadel and Massoud } \\
\text { (2000) }\end{array}$ & Particulate matter in urban areas: health-based economic assessment & Article & 62 \\
\hline 8th & Baveye et al. (1999) & $\begin{array}{l}\text { Mass balance and distribution of sludge-borne trace elements in a silt loam soil } \\
\text { following long-term applications of sewage sludge }\end{array}$ & Article & 58 \\
\hline 8th & Loutfy et al. (2006). & $\begin{array}{l}\text { Dietary intake of dioxins and dioxin-like PCBs, due to the consumption of dairy } \\
\text { products, fish/seafood and meat from Ismailia city, Egypt }\end{array}$ & Article & 58 \\
\hline 10th & Louiz et al. (2008) & $\begin{array}{l}\text { Monitoring of dioxin-like, oestrogenic and anti-androgenic activities in sediments of } \\
\text { the Bizerta lagoon (Tunisia) by means of in vitro cell-based bioassays: contribution } \\
\text { of low concentrations of polynuclear aromatic hydrocarbons (PAHs) }\end{array}$ & Article & 57 \\
\hline 10th & Rocher et al. (2004) & $\begin{array}{l}\text { Hydrocarbons and heavy metals in the different sewer deposits in the "Le Marais" } \\
\text { catchment (Paris, France): stocks, distributions and origins }\end{array}$ & Article & 57 \\
\hline
\end{tabular}

$S C R$ standard competition ranking

${ }^{a}$ Equal documents in terms of number of citations have the same number of ranking, and then, a gap is left in the numbers of ranking

Table 4 Top ten highly prolific institutions that published research from Arab world in Science of the Total Environment journal

\begin{tabular}{llll}
\hline SCR $^{\text {a }}$ & Name of institution & Country & No. of documents $(\%)$ \\
\hline 1 st & American University of Beirut & Lebanon & $16(7.4)$ \\
2nd & King Abdulaziz University & Saudi Arabia & $15(7.0)$ \\
3 rd & King Saud University & Saudi Arabia & $9(4.2)$ \\
4 th & National Research Centre & Egypt & $7(3.3)$ \\
4 th & King Faisal Specialist Hospital and Research Centre & Saudi Arabia & $7(3.3)$ \\
4 th & University of Kuwait & Kuwait & $7(3.3)$ \\
7 th & Universite Cadi Ayyad & Kuwait & $6(2.8)$ \\
7 th & Kuwait Institute for Scientific Research & Kuwait & $6(2.8)$ \\
7 th & CSIC-Instituto de Diagnostico Ambiental y Estudios del Agua IDAEA & Spain & $6(2.8)$ \\
10 th & King Saud University College of Science & Saudi Arabia & $5(2.3)$ \\
10 th & Atomic Energy Authority of Egypt & Egypt & $5(2.3)$ \\
10 th & King Fahd University of Petroleum and Minerals & Saudi Arabia & $5(2.3)$ \\
10 th & Universitat de Girona & Spain & $5(2.3)$ \\
10 th & University of Birmingham & UK & $5(2.3)$ \\
10 th & Yarmouk University & Jordan & $5(2.3)$ \\
10 th & Atomic Energy Commission of Syria & Syrian Arab Republic & $5(2.3)$ \\
10 th & Arabian Gulf University & Bahrain & $5(2.3)$ \\
\hline S & & &
\end{tabular}

SCR standard competition ranking

a Equal institutions have the same number of ranking, and then, a gap is left in the numbers of rankings 
Table 5 Top ten most prolific Arab and international authors who published research from Arab world in Science of the Total Environment journal

\begin{tabular}{|c|c|c|c|c|c|c|}
\hline $\mathrm{SCR}^{\mathrm{a}}$ & Name of the author & $\begin{array}{l}\text { Name of the institution, } \\
\text { country }\end{array}$ & $\begin{array}{l}\text { No. of documents } \\
(\%)\end{array}$ & $\begin{array}{l}\text { Total documents } \\
\text { by the author }{ }^{\mathrm{b}}\end{array}$ & $h$-index & $\begin{array}{l}\text { Total } \\
\text { citations }\end{array}$ \\
\hline 1 st & El-Fadel, M. & $\begin{array}{l}\text { American University of Beirut, } \\
\text { Lebanon }\end{array}$ & $7(3.3)$ & 172 & 26 & 2282 \\
\hline 1 st & Al-Saleh, I. & $\begin{array}{l}\text { King Faisal Specialist Hospital } \\
\text { and Research Centre, Saudi } \\
\text { Arabia }\end{array}$ & $7(3.3)$ & 97 & 19 & 1264 \\
\hline $3 r d$ & Madany, I.M. & University of Bahrain, Bahrain & $5(2.3)$ & 38 & 13 & 571 \\
\hline $3 \mathrm{rd}$ & Othman, I. & $\begin{array}{l}\text { Atomic Energy Commission of } \\
\text { Syria, Syrian Arab Republic }\end{array}$ & $5(2.3)$ & 31 & 11 & 418 \\
\hline $3 \mathrm{rd}$ & Kannan, K. & $\begin{array}{l}\text { King Abdulaziz University, } \\
\text { Department of Biochemistry, } \\
\text { Jeddah, Saudi Arabia }\end{array}$ & $5(2.3)$ & 516 & 84 & 26,178 \\
\hline $3 \mathrm{rd}$ & Barcelo İ, D. & $\begin{array}{l}\text { CSIC-Instituto de Diagnostico } \\
\text { Ambiental y Estudios del } \\
\text { Agua (IDAEA), Department } \\
\text { of Environmental Chemistry, } \\
\text { Barcelona, Spain }\end{array}$ & $5(2.3)$ & 1085 & 92 & 38,527 \\
\hline 7th & Bu-Olayan, A.H. & University of Kuwait, Kuwait & $4(1.9)$ & 37 & 9 & 231 \\
\hline 7th & Harakeh, S. & $\begin{array}{l}\text { King Abdulaziz University, } \\
\text { Saudi Arabia }\end{array}$ & $4(1.9)$ & 73 & 13 & 558 \\
\hline 7 th & Lekouch, N. & $\begin{array}{l}\text { Trace Element Institute for } \\
\text { UNESCO, Morocco }\end{array}$ & $4(1.9)$ & 11 & 5 & 1165 \\
\hline 7 th & Sedki, A. & $\begin{array}{l}\text { Faculte des Sciences Semlalia, } \\
\text { Marakech, Morocco }\end{array}$ & $4(1.9)$ & 16 & 5 & 176 \\
\hline
\end{tabular}

$S C R$ standard competition ranking, $I F$ impact factor

${ }^{a}$ Equal authors have the same number of ranking, and then, a gap is left in the numbers of rankings

b Total documents, $h$-index and total citations have been harvested from Scopus database, and these figures could be differ when using other research databases

Arabia $(9 ; 4.2 \%)$. There were five universities out of seventeen universities in the list of top ten productive institutions at Arab world level from Saudi Arabia. The distinguished contributions of Saudi Arabia's universities are referred to the fact that Saudi Arabia has set up a group of research centres of excellence which are concerned with environmental research such as Environmental Studies Center of Excellence at King Abdulaiz University, Renewable Energy Research Center of Excellence at King Fahd University for Petroleum and Minerals and Center of Excellence of Desalination in King Abdulaiz University. Two institutions from Egypt were listed in the list of most prolific institutions in Arab world. The National Research Center (NRC) which takes up the fourth position is considered as the largest centre of research in the Middle East region in fields of science and technology. This research centre serves scientific research cooperation at national, regional and international levels including technology transfer (Lorenzo 2010). Another interesting finding was from Lebanon, where the scientific research is a universitydriven activity (Larzillière 2010). Lebanon occupies the fourth position among Arab countries in terms of research productivity, and American University of Beirut, Lebanon, was responsible in producing $84 \%$ of total research productivity of Lebanon. This university was in the first position in the list of top prolific universities at Arab world level, and one of the two most prolific authors at Arab world level was from this university (El-Fadel, Mutasem E.). Most of published research from Lebanon was related to air pollution, climate change, quality of water and waterborne diseases, land use, heavy metals, wastewater, health care, contamination of food, and their associations with public health. The majority of case studies were conducted in Lebanon with some in France as a result of strong research collaboration between the two countries.

Table 5 presents the list of ten most prolific authors from Arab world and international authors who collaborated with researchers from Arab world in research that has been published in Science of the Total Environment journal. Three authors out of ten were from universities in Saudi Arabia. This finding is in connection with the active participation of Saudi Arabia in the published research under examination. 
Table 6 List of top ten journals that mostly cited articles published from Arab world in Science of the Total Environment journal

\begin{tabular}{llll}
\hline SCR $^{\text {a }}$ & Journal $^{\text {b }}$ & Frequency & IF $^{\mathrm{c}}$ \\
\hline 1st & Environmental Monitoring and Assessment & 91 & 1.633 \\
2nd & Chemosphere & 75 & 3.698 \\
3rd & Environmental Science and Pollution Research & 68 & 2.76 \\
4th & Journal of Hazardous Materials & 46 & 4.836 \\
5th & Environmental Pollution & 45 & 4.839 \\
6th & Bulletin of Environmental Contamination and Toxicology & 43 & 1.191 \\
6th & Marine Pollution Bulletin & 43 & 3.099 \\
8th & Atmospheric Environment & 42 & 3.459 \\
9th & Biological Trace Element Research & 37 & 1.798 \\
10th & Ecotoxicology and Environmental Safety & 35 & 3.13 \\
\hline
\end{tabular}

$S C R$ standard competition ranking, IF impact factor

${ }^{a}$ Equal journals have the same number of ranking, and then, a gap is left in the numbers of rankings

b The self-citations by Science of the Total Environment journal were (193) citations

c Impact factors of journals were documented from Journal Citation Reports (JCR) 2015
As displayed in Table 6, which listed the journals that mostly cited articles published from Arab world in Science of the Total Environment journal, all journals were closely related to the interface of environment and had official IFs as listed in the JCR 2015. Most of these journals are concerned with specific topics in environmental sciences and not as in case of Science of the Total Environment journal which is more general in its scope than the others. The published research from Arab world gained citations by 3410 documents in 152 journals including the journal itself which recorded the most attracted citations. The majority of these documents were articles $(2963 ; 87.0 \%)$, followed by review articles $(237 ; 7.0 \%)$, conference papers $(108$; $3.2 \%)$, and the remaining $(102 ; 3.0 \%)$ were assorted as other types of publications such as books, letters and notes. The most country that cited published research from Arab world was the USA (in 446 documents), followed by China (in 406 documents), India (in 258 documents), Saudi Arabia (in 208 documents) and Spain (in 207 documents). Furthermore, the institutions that mostly cited published research from Arab world were King Abdulaziz University, Saudi Arabia (in 69 documents), Chinese Academy of Sciences, China (in 56 documents), and American University of Beirut, Lebanon (in 37 documents). For the authors that mostly cited published research from Arab world, they were Khan, S.B. (in 31 documents); Asiri, A.M. (in 30 documents); and Rahman, M.M (in 24 documents). The three authors were all from King Abdulaziz University, Saudi Arabia. Articles from Arab world were mostly cited by articles related to environmental science, medicine, agricultural and biological sciences, and earth and planetary sciences. Two authors who are heavily cited articles from Arab world in this journal were in the list of ten top prolific authors (They were Madany, I. M. and Al-
Saleh, I.). This might be partially explained the high rates of citations by the journal itself.

The comparative analysis outcomes, which are displayed in Fig. 2 and Table 7, have shed the light on the performance of the top two most prolific countries in Arab world (Saudi Arabia and Egypt) in comparison with the three non-Arab Middle Eastern countries (Iran, Turkey and Israel). This comparative analysis examined the progress of research in terms of yearly productivity as shown in Fig. 2. Furthermore, it examined the volume of published research, $h$-index, total citations, collaborated countries, research productivity from collaboration, most productive institutions and most prolific authors as shown in Table 7. The research activities at Arab world level have begun ten years later compared with the global. Otherwise, research activities in Saudi Arabia and Egypt were started earlier in comparison with other nations in the Middle East region with exception of Israel which was the first to start publishing research in Science of the Total Environment journal in Middle East region.

Compared with other non-Arab Middle Eastern countries, the research productivity from Saudi Arabia or Egypt was lesser than that from Turkey ( 83 documents) and Israel (87 documents) and but higher than that from Iran (34 documents). This indicated an evident large gap in terms of research productivity between the two Arab countries (Saudi Arabia and Egypt) and each of Israel and Turkey. Generally, the performance of Turkey was the best in most indicators. The progress of research of Turkey is strikingly proved as the output of Turkey at global level trebled from $0.7 \%$ in 2000 to $1.9 \%$ in 2009 (Adams et al. 2011). Although the productivity of Iran was low in this study, the three countries (Turkey, Iran and Israel) occupy the 20th, 22nd and 23rd positions, respectively, in the list of top 
Fig. 2 No. of published documents from the two most prolific countries at Arab world level (Saudi Arabia and Egypt) in comparison with the three non-Arab Middle Eastern countries (Iran, Turkey and Israel) in Science of the Total Environment Journal

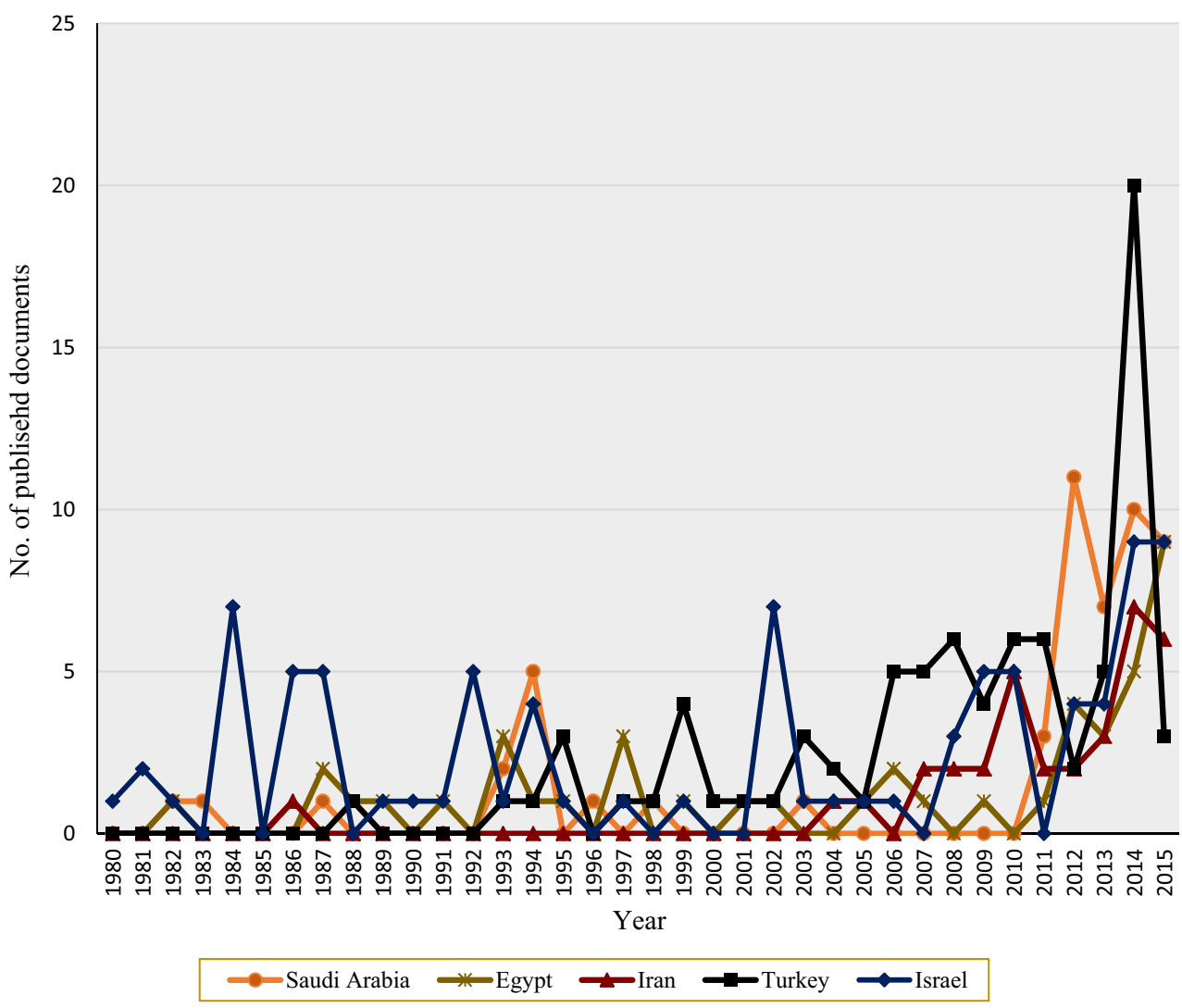

productive countries in all fields of research with a clear superiority of Israel in terms of research quality indicators such as $h$-index, citations and average citations, followed by Turkey and lastly Iran (SCImago 2016). The rankings of the three non-Arab Middle Eastern countries (Israel, Turkey and Iran) in Science of the Total Environment journal in terms of productivity were (33rd, 34th and 49th), respectively.

Further to comparative analysis outcomes, the content analysis of abstracts as illustrated in Fig. 3 showed similarity in discussed topics across non-Arab Middle Eastern countries, Arab world and the two most prolific countries in Arab world (Saudi Arabia and Egypt). Sampling, concentrations, levels, exposure, water and air were the most frequent terms in the abstracts which shed light on the main research activities that related mostly to field studies, collecting samples and measuring concentrations of different materials (air pollutants, toxic materials, heavy elements such as lead, etc.). In case of Israel, there was more focus on topics related to soil research with respect to agriculture, pollution by heavy metals, airborne pollution, effect of grey water irrigation on soil properties, and soil components in rain water.

It was found that the most prevalent research areas of interests in Arab world comprise environmental science $(215 ; 100 \%)$, followed by medicine $(50 ; 23.3 \%)$ and earth and planetary sciences $(24 ; 11.2 \%)$. The total surpasses $100 \%$ because of data overlapping due to multidiscipline interaction. These findings point to the high interactions between the examined environmental issues and their effects on public health in this region.

To the best of author's knowledge, this work is the first of its nature to acquire information related to bibliometric indicators of research published in a leading environmental journal by a geographic area (Arab world) and to conduct a comparative and content analysis of published research from this region with comparison with other nations in the same region that are facing the same environmental concerns and risks. This evaluation will be of advantage to draw the attention of researchers to the status of research in this vital filed and to help in advancing the environmental research in this most vulnerable region. This analysis is not without limitations, and most of them are the same as those in other bibliometric analyses. This study was limited to one journal and cannot give detailed perspective regarding environmental research in Arab world. Despite that, this study provides a good representative example of the present status of environmental research in Arab world. Additional limitation is related to the number of citations which were limited to citations extracted from Scopus database. Although figures of citations for the published research might vary from one search engine to other, 
Table 7 Comparative analysis outputs between Arab world, two most prolific countries-Arab world and the three non-Arab Middle East countries

\begin{tabular}{|c|c|c|c|c|c|c|}
\hline \multirow[t]{2}{*}{ Region } & \multicolumn{6}{|l|}{ Country field } \\
\hline & Arab World & Saudi Arabia & Egypt & Israel & Turkey & Iran \\
\hline $\begin{array}{l}\text { No. of } \\
\text { published } \\
\text { documents }\end{array}$ & 215 & 53 & 44 & 87 & 83 & 34 \\
\hline$h$-Index & 31 & 15 & 15 & 20 & 26 & 14 \\
\hline $\begin{array}{l}\text { Total no. of } \\
\text { citations }\end{array}$ & 3616 & 595 & 795 & 1108 & 2239 & 564 \\
\hline $\begin{array}{l}\text { Mean of } \\
\text { citations }\end{array}$ & 16.82 & 11.23 & 18.1 & 12.74 & 27.0 & 17.0 \\
\hline $\begin{array}{l}\text { Median of } \\
\text { citations } \\
\text { (Q1-Q3) }\end{array}$ & $9(4.0-18.0)$ & $7(4.0-15.0)$ & $8(4.0-21.0)$ & $8(4.0-18.0)$ & $14(4.0-35.0)$ & $\begin{array}{l}13.5 \\
\quad(5.0-20.25)\end{array}$ \\
\hline $\begin{array}{l}\text { No. of } \\
\text { collaborated } \\
\text { countries }\end{array}$ & 40 & 23 & 24 & 20 & 28 & 10 \\
\hline $\begin{array}{l}\text { No. of } \\
\text { documents } \\
\text { from } \\
\text { collaboration } \\
(\%)\end{array}$ & $140(65.0)$ & $36(67.9)$ & $33(75.0$ & 24 (27.6) & $25(30.0)$ & $14(41.2)$ \\
\hline $\begin{array}{l}\text { Most } \\
\text { collaborated } \\
\text { country (no. } \\
\text { of } \\
\text { documents- } \\
\% \text { ) }\end{array}$ & $\begin{array}{l}\text { France } \\
\qquad(29-20.7)\end{array}$ & UK(10-27.8) & $\begin{array}{l}\text { Germany } \\
\quad(12-36.4)\end{array}$ & USA (8-33.3) & USA (7-28.0) & USA(5-35.7) \\
\hline $\begin{array}{l}\text { Most productive } \\
\text { institution } \\
\text { (no. of } \\
\text { documents- } \\
\% \text { ) }\end{array}$ & $\begin{array}{l}\text { American } \\
\text { University of } \\
\text { Beirut, } \\
\text { Lebanon } \\
(16-7.4)\end{array}$ & $\begin{array}{l}\text { King Abdulaziz } \\
\text { University } \\
(15-28.3)\end{array}$ & $\begin{array}{l}\text { National } \\
\text { Research } \\
\text { Center } \\
(7-16)\end{array}$ & $\begin{array}{l}\text { Ben-Gurion } \\
\text { University of the } \\
\text { Negev (23-26.4) }\end{array}$ & $\begin{array}{l}\text { Istanbul TeknikUniversitesi } \\
\quad(16-19.3)\end{array}$ & $\begin{array}{l}\text { University of } \\
\text { Tehran } \\
(7-20.6)\end{array}$ \\
\hline \multirow[t]{2}{*}{$\begin{array}{l}\text { Most prolific } \\
\text { author (no. of } \\
\text { documents- } \\
\% \text { ) institution }\end{array}$} & $\begin{array}{l}\text { El-Fadel, M. } \\
\text { (7-3.3)- } \\
\text { American } \\
\text { University of } \\
\text { Beirut, } \\
\text { Lebanon }\end{array}$ & $\begin{array}{l}\text { Al-Saleh, I. } \\
\text { (7-13.2)- } \\
\text { King Faisal } \\
\text { Specialist } \\
\text { Hospital and } \\
\text { Research } \\
\text { Centre, Saudi } \\
\text { Arabia }\end{array}$ & $\begin{array}{l}\text { Abou-Elela, } \\
\text { Sohair I } \\
\text { (3-6.8)- } \\
\text { National } \\
\text { Research } \\
\text { Centre, } \\
\text { Egypt }\end{array}$ & $\begin{array}{l}\text { Goldsmith, J.R. } \\
\text { (6-6.9)-Ben- } \\
\text { Gurion University } \\
\text { of the Negev, } \\
\text { Israel }\end{array}$ & $\begin{array}{l}\text { Kindap, T. (6-7.2)- } \\
\text { Istanbul Teknik } \\
\text { Universitesi, Turkey }\end{array}$ & $\begin{array}{l}\text { Esmaili-Sari, } \\
\text { A. (3-8.8)- } \\
\text { Tarbiat } \\
\text { Modares } \\
\text { University, } \\
\text { Iran }\end{array}$ \\
\hline & 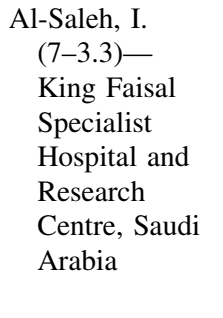 & & $\begin{array}{l}\text { Ahmed, A.A } \\
\text { (3-6.8)- } \\
\text { Cairo } \\
\text { University, } \\
\text { Department } \\
\text { of } \\
\text { Chemistry, } \\
\text { Cairo, Egypt }\end{array}$ & $\begin{array}{l}\text { Friedler, E. } \\
\text { (6-6.9)- } \\
\text { Technion- } \\
\text { Israel-Haifa, } \\
\text { Israel Gross, A. } \\
\text { (6-6.9)—Ben- } \\
\text { Gurion University } \\
\text { of the Negev, } \\
\text { Israel }\end{array}$ & $\begin{array}{l}\text { Odabasi, M. (6-7.2)- } \\
\text { DokuzEylulUniversitesi, } \\
\text { Turkey }\end{array}$ & $\begin{array}{l}\text { Yunesian, M. } \\
\text { (3-8.8)- } \\
\text { Tehran } \\
\text { University of } \\
\text { Medical } \\
\text { Sciences, } \\
\text { Tehran, Iran }\end{array}$ \\
\hline $\begin{array}{l}\text { Prevalent area } \\
\text { of interest }\end{array}$ & $\begin{array}{l}\text { Environmental } \\
\text { science } \\
(215-100.0 \%)\end{array}$ & $\begin{array}{l}\text { Environmental } \\
\text { science } \\
\quad(53-100.0 \%)\end{array}$ & $\begin{array}{l}\text { Environmental } \\
\text { science } \\
\quad(44-100.0 \%)\end{array}$ & $\begin{array}{l}\text { Environmental } \\
\text { science } \\
(87-100.0 \%)\end{array}$ & $\begin{array}{l}\text { Environmental science } \\
\quad(83-100.0 \%)\end{array}$ & $\begin{array}{l}\text { Environmental } \\
\text { science } \\
\quad(34-100.0 \%)\end{array}$ \\
\hline
\end{tabular}




\begin{tabular}{|c|c|c|}
\hline 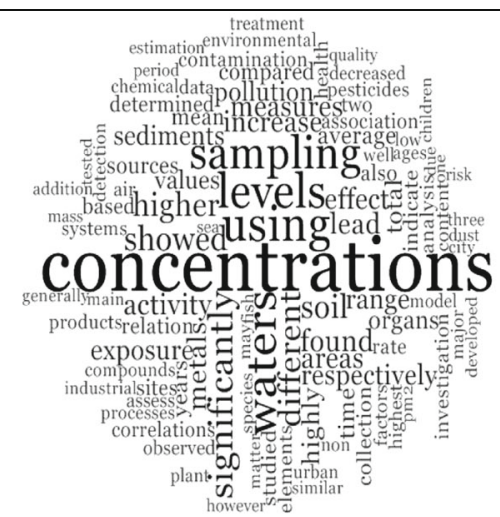 & 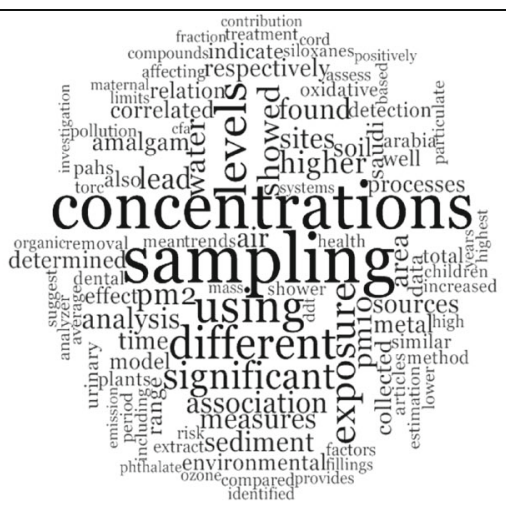 & 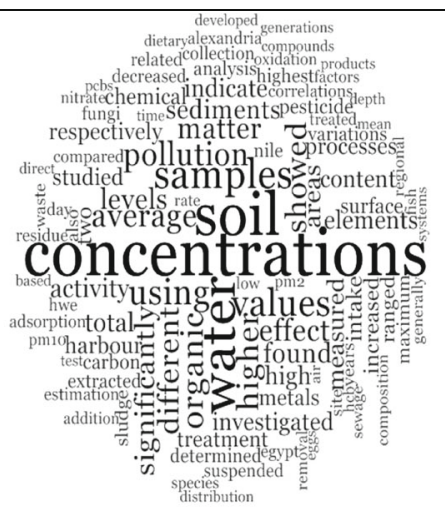 \\
\hline $\mathbf{A}$ & B & C \\
\hline 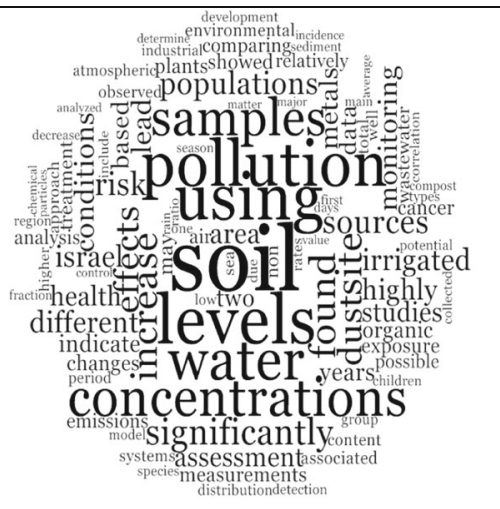 & 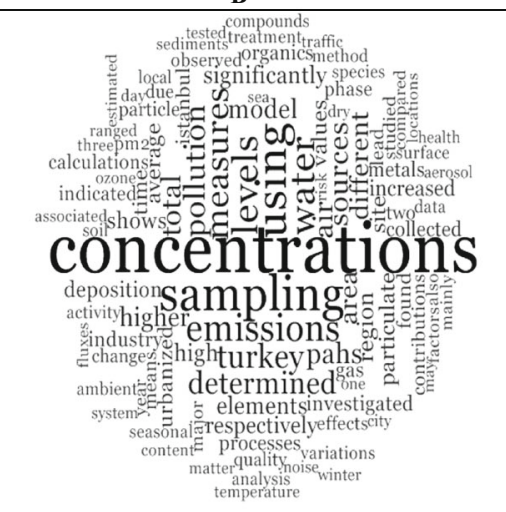 & 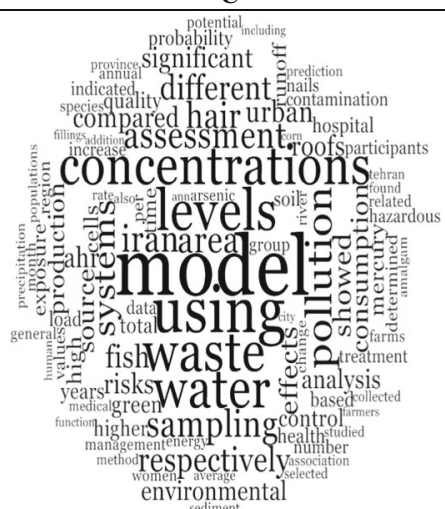 \\
\hline & & \\
\hline
\end{tabular}

Fig. 3 Tag clouds of words appearing in abstracts of published research in Science of the Total Environment Journal from Arab world; the two most prolific countries-Arab world (Saudi Arabia and

Scopus database sustains as one of the leading search tools which are available in the field of analysing, comparing and tracking citations among different institutions and research groups (De Granda-Orive et al. 2011).

\section{Conclusion}

An overview of the environmental research published from Arab world in a leading environmental journal was presented in this work with information related to different bibliometric indicators. The outcomes were compared with those of other nations in the same region (Iran, Turkey and Israel). The followed approach based on sourcing publications and gathering systematic data related to these publications from Scopus database. Subsequently, bibliometric techniques and statistical measures have been used to identify the different bibliometric indicators.

The research productivity from Arab world has significantly increased in the last 4 years. Its Fig. $(1.25 \%$ of
Egypt) and the three non-Arab Middle Eastern countries (Iran, Turkey and Israel). a Arab World, b Saudi Arabia, c Egypt, d Israel, e Turkey, f Iran

global research productivity) was nearly in agreement with Arab world's contributions to worldwide research in all fields of science. Broad differences in terms of research productivity and other indicators among Arab world countries are witnessed with clear achievements by Saudi Arabia and Egypt which are contributed by more than $45 \%$ (97 documents) out of total research produced by Arab world countries. The contributions of institutions and authors from Saudi Arabia were also distinct. There were five institutions from Saudi Arabia in the list of top ten most productive institutions and three authors in the list of top ten most prolific authors.

The two most influential countries in Arab world (Saudi Arabia and Egypt) showed significant performance deficit in terms of most bibliometric indicators (i.e. research productivity, $h$-index and total citations) in comparison with performance of each of Turkey and Israel. Otherwise, they are doing better than Iran. Rationally, the major focus of the examined body of the literature published by Arab world and non-Arab Middle Eastern countries was similar 
and the most discussed topics were concerned with air pollution, pollution of aquatic environments, heavy metals, polluted soils and environmental risks effects on the public health. Most of these studies were performed as field studies.

Despite the lags in scientific research output of this region, the commitments to boost research activities are evident by the general increase in number of publications with progress in time. This commitment should be accompanied by initiatives to strengthening networks of collaboration between research institutions in Arab world and their counterparts in developed countries. The governments should increase the investment in environmental research as a priority to eliminate the potential risks associated with the degradation in this region environment.

Saudi Arabia and Egypt as the Arab world's leading countries in this field of research and in most of scientific research disciplines should address the challenges that are facing the promotion of scientific research in the total environmental research and should shape in collaboration with other Arab countries the future investments in technological innovations that have a great potential for mitigating the environmental degradation. There should be additional focus on publishing review articles from Arab world, as they were negligible relative to articles with original data. As a last conclusion, this work is helpful in identifying the status of research originated from Arab world in essential discipline. Additionally, it is useful as an informative study to assist policy makers and researchers in assessing the performance indicators of research activities. The followed methodology is applicable for implementation in other subjects of research.

Acknowledgements Open access funding provided by Graz University of Technology. The authors would like to thank Graz University of Technology, Graz, Austria, for providing the opportunity to access the most recent information sources such as the Scopus database.

Open Access This article is distributed under the terms of the Creative Commons Attribution 4.0 International License (http:// creativecommons.org/licenses/by/4.0/), which permits unrestricted use, distribution, and reproduction in any medium, provided you give appropriate credit to the original author(s) and the source, provide a link to the Creative Commons license, and indicate if changes were made.

\section{References}

Acosta M, Coronado D, Fernández A (2009) Exploring the quality of environmental technology in Europe: evidence from patent citations. Scientometrics 80:131-152. doi:10.1007/s11192-0082057-0
Adams J (2012) Collaborations: the rise of research networks. Nature 490:335-336. doi:10.1038/490335a

Adams J, King C, Pendlebury D, Hook D, Wilsdon J (2011) Global research report Middle East: exploring the changing landscape of Arabian, Persian, and Turkish research. http://researchanalytics. thomsonreuters.com/grr/. Accessed 4 May 2016

Ahmadi A, Abbaspour M, Arjmandi R, Abedi Z (2015) Air quality risk index (AQRI) and its application for a megacity. Int $\mathbf{J}$ Environ Sci Technol 12:3773-3780. doi:10.1007/s13762-0150837-7

Ahmed Hussein M (2008) Costs of environmental degradation. Manag Environ Qual Int J 19:305-317. doi:10.1108/ 14777830810866437

Ahmed K, Shahbaz M, Qasim A, Long W (2015) The linkages between deforestation, energy and growth for environmental degradation in Pakistan. Ecol Indic 49:95-103. doi:10.1016/j. ecolind.2014.09.040

Akhtar-Schuster $M$ et al (2016) Designing a new science-policy communication mechanism for the UN convention to combat desertification. Environ Sci Policy 63:122-131. doi:10.1016/j. envsci.2016.03.009

Alshumaimri A, Aldridge T, Audretsch DB (2010) The university technology transfer revolution in Saudi Arabia. J Technol Transf 35:585-596. doi:10.1007/s10961-010-9176-5

Al-Yousuf MH, El S, Al-Ghais SM (2000) Trace metals in liver, skin and muscle of Lethrinus lentjan fish species in relation to body length and sex. Sci Total Environ 256:87-94. doi:10.1016/ S0048-9697(99)00363-0

Anderson T, Shattuck J (2012) Design-based research: a decade of progress in education research? Educ Res 41:16-25. doi:10. 3102/0013189x11428813

Armfield NR, Edirippulige S, Caffery LJ, Bradford NK, Grey JW, Smith AC (2014) Telemedicine-a bibliometric and content analysis of 17,932 publication records. Int $\mathrm{J}$ Med Inform 83:715-725. doi:10.1016/j.ijmedinf.2014.07.001

Baveye P, McBride MB, Bouldin D, Hinesly TD, Dahdoh MS, Abdelsabour MF (1999) Mass balance and distribution of sludge-borne trace elements in a silt loam soil following long-term applications of sewage sludge. Sci Total Environ 227:13-28. doi:10. 1016/S0048-9697(98)00396-9

Benamer HT, Bakoush O (2009) Arab nations lagging behind other Middle Eastern countries in biomedical research: a comparative study. BMC Med Res Methodol 9:26. doi:10.1186/1471-2288-926

Boumedjout H (2010) Arab world must innovate in science, says UNESCO. http://www.natureasia.com/en/nmiddleeast/article/10. 1038/nmiddleeast.2010.224. Accessed 30 Sept 2016

Carleton TA, Hsiang SM (2016) Social and economic impacts of climate. Science. doi:10.1126/science.aad9837

Cocârţă DM, Neamţu S, Reşetar Deac AM (2016) Carcinogenic risk evaluation for human health risk assessment from soils contaminated with heavy metals. Int $\mathrm{J}$ Environ Sci Technol 13:2025-2036. doi:10.1007/s13762-016-1031-2

Damak M, Mahmoudi SR, Hyder MN, Varanasi KK (2016) Enhancing droplet deposition through in situ precipitation. Nat Commun 7:12560. doi: $10.1038 /$ ncomms 12560

De Battisti F, Salini S (2013) Robust analysis of bibliometric data. Stat Methods Appl 22:269-283

De Granda-Orive JI, Alonso-Arroyo A, Roig-Vázquez F (2011) Which data base should we use for our literature analysis? Web of Science versus SCOPUS. Arch Bronconeumol 47:213

Deutsch C, Ferrel A, Seibel B, Portner HO, Huey RB (2015) Ecophysiology. Climate change tightens a metabolic constraint on marine habitats. Science 348:1132-1135. doi:10.1126/ science.aaa1605 
Dragos CM, Dragos SL (2013) Bibliometric approach of factors affecting scientific productivity in environmental sciences and ecology. Sci Total Environ 449:184-188. doi:10.1016/j. scitotenv.2013.01.057

Dubos R (1976) Symbiosis between the earth and humankind. Science 193:459-462. doi:10.1126/science.193.4252.459

Durant JR, Evans GA, Thomas GP (1989) The public understanding of science. Nature 340:11-14. doi:10.1038/340011a0

Egghe L (2006) An improvement of the h-index: the g-index. ISSI Newsl 2:8-9

Elasha BO (2010) Mapping of climate change threats and human development impacts in the Arab region. http://www.arab-hdr. org/publications/other/ahdrps/paper02-en.pdf. Accessed $30 \mathrm{Sept}$ 2016

El-Fadel M, Massoud M (2000) Particulate matter in urban areas: health-based economic assessment. Sci Total Environ 257:133-146. doi:10.1016/S0048-9697(00)00503-9

Elminir HK (2005) Dependence of urban air pollutants on meteorology. Sci Total Environ 350:225-237. doi:10.1016/j.scitotenv. 2005.01.043

Elsevier (2016) Science of the total environment. http://www. journals.elsevier.com/science-of-the-total-environment/. Accessed 4 May 2016

El-Zein A et al (2014) Health and ecological sustainability in the Arab world: a matter of survival. Lancet 383:458-476. doi:10.1016/ S0140-6736(13)62338-7

Falagas ME, Pitsouni EI, Malietzis GA, Pappas G (2008) Comparison of PubMed, Scopus, Web of Science, and Google Scholar: strengths and weaknesses. FASEB J Off Publ Fed Am Soc Exp Biol 22:338-342. doi:10.1096/fj.07-9492LSF

Fu H-Z, Ho Y-S (2015) A bibliometric analysis of the Journal of Membrane Science (1976-2010). Electron Libr 33:698-713. doi:10.1108/el-12-2013-0221

Fu HZ, Wang MH, Ho YS (2013) Mapping of drinking water research: a bibliometric analysis of research output during 1992-2011. Sci Total Environ 443:757-765. doi:10.1016/j. scitotenv.2012.11.061

García-Lillo F, Úbeda-García M, Marco-Lajara B (2016) The intellectual structure of research in hospitality management: a literature review using bibliometric methods of the journal International Journal of Hospitality Management. Int J Hosp Manag 52:121-130. doi:10.1016/j.ijhm.2015.10.007

Gazni A, Sugimoto CR, Didegah F (2012) Mapping world scientific collaboration: authors, institutions, and countries. J Am Soc Inf Sci Technol 63:323-335. doi:10.1002/asi.21688

Harford JB (2015) Barriers to overcome for effective cancer control in Africa. Lancet Oncol 16:e385-e393. doi:10.1016/S14702045(15)00160-6

Havemann F, Heinz M, Kretschmer H (2006) Collaboration and distances between German immunological institutes-a trend analysis. J Biomed Discov Collab 1:6. doi:10.1186/1747-5333-16

Hirsch JE (2005) An index to quantify an individual's scientific research output. Proc Natl Acad Sci USA 102:16569-16572. doi:10.1073/pnas.0507655102

Holdren JP (2008) Presidential address: science and technology for sustainable well-being. Science 319:424-434. doi:10.1126/ science. 1153386

Hu J, Ma Y, Zhang L, Gan F, Ho YS (2010) A historical review and bibliometric analysis of research on lead in drinking water field from 1991 to 2007. Sci Total Environ 408:1738-1744. doi:10. 1016/j.scitotenv.2009.12.038

Hull D, Pettifer SR, Kell DB (2008) Defrosting the digital library: bibliographic tools for the next generation web. PLoS Comput Biol 4:e1000204. doi:10.1371/journal.pcbi.1000204
Iqbal J, Gorai AK, Katpatal YB, Pathak G (2014) Development of GIS-based fuzzy pattern recognition model (modified DRASTIC model) for groundwater vulnerability to pollution assessment. Int J Environ Sci Technol 12:3161-3174. doi:10.1007/s13762-0140693-x

Jain S et al (2015) Bibliometric analysis of journal of clinical and diagnostic research (dentistry section; 2007-2014). J Clin Diagn Res 9:ZC47-ZC51. doi:10.7860/JCDR/2015/11994.5834

Juřička D, Muchová M, Elbl J, Pecina V, Kynický J, Brtnický M, Rosická Z (2016) Construction of remains of small-scale mining activities as a possible innovative way how to prevent desertification. Int J Environ Sci Technol 13:1405-1418. doi:10.1007/ s13762-016-0967-6

Katz JS, Plevin J (1998) Environmental science in the UK: a bibliometric study. Res Eval 7:39-52. doi:10.1093/rev/7.1.39

Khan MA, Ho YS (2012) Top-cited articles in environmental sciences: merits and demerits of citation analysis. Sci Total Environ 431:122-127. doi:10.1016/j.scitotenv.2012.05.035

Khan SB, Faisal M, Rahman MM, Jamal A (2011) Exploration of $\mathrm{CeO}$ (2) nanoparticles as a chemi-sensor and photo-catalyst for environmental applications. Sci Total Environ 409:2987-2992. doi:10.1016/j.scitotenv.2011.04.019

Kosmas C, Karamesouti M, Kounalaki K, Detsis V, Vassiliou P, Salvati L (2016) Land degradation and long-term changes in agro-pastoral systems: an empirical analysis of ecological resilience in Asteroussia-Crete (Greece). Catena 147:196-204. doi:10.1016/j.catena.2016.07.018

Kulkarni AV, Aziz B, Shams I, Busse JW (2009) Comparisons of citations in Web of Science, Scopus, and Google Scholar for articles published in general medical journals. JAMA 302:1092-1096. doi:10.1001/jama.2009.1307

Larzillière P (2010) Scientific production and researchers' experience in Jordan. Sci Technol Soc 15:309-338. doi:10.1177/ 097172181001500206

Li J, Zheng Y, Luo X, Lin Z, Zhang W, Wang X (2016a) PAH contamination in Beijing's topsoil: a unique indicator of the megacity's evolving energy consumption and overall environmental quality. Sci Rep 6:33245. doi:10.1038/srep33245

Li Q, Zhang C, Shen Y, Jia W, Li J (2016b) Quantitative assessment of the relative roles of climate change and human activities in desertification processes on the Qinghai-Tibet Plateau based on net primary productivity. Catena 147:789-796. doi:10.1016/j. catena.2016.09.005

Lorenzo A (2010) Membrane technology in water treatment in the mediterranean region (ProMembrane). IWA, London

Louiz I et al (2008) Monitoring of dioxin-like, estrogenic and antiandrogenic activities in sediments of the Bizerta lagoon (Tunisia) by means of in vitro cell-based bioassays: contribution of low concentrations of polynuclear aromatic hydrocarbons (PAHs). Sci Total Environ 402:318-329. doi:10.1016/j. scitotenv.2008.05.005

Loutfy N, Fuerhacker M, Tundo P, Raccanelli S, El Dien AG, Ahmed MT (2006) Dietary intake of dioxins and dioxin-like PCBs, due to the consumption of dairy products, fish/seafood and meat from Ismailia city, Egypt. Sci Total Environ 370:1-8. doi:10.1016/j. scitotenv.2006.05.012

Mamtora J, Wolstenholme JK, Haddow G (2013) Environmental sciences research in northern Australia, 2000-2011: a bibliometric analysis within the context of a national research assessment exercise. Scientometrics 98:265-281. doi:10.1007/ s11192-013-1037-1

Masood E (2002) Arab science: blooms in the desert. Nature 416:120-122. doi:10.1038/416120a

Maziak W (2005) Global voices of science. Science in the Arab world: vision of glories beyond. Science 308:1416-1418. doi:10. 1126/science. 1114330 
Meho LI, Rogers Y (2008) Citation counting, citation ranking, and h-index of human-computer interaction researchers: a comparison of Scopus and Web of Science. J Am Soc Inf Sci Technol 59:1711-1726. doi:10.1002/asi.v59:11

Meo SA (2015) Saudi Arabia: a future regional hub for advanced education, research, science and technology. J Pak Med Assoc 65:1112-1115

Minguillo D, Tijssen R, Thelwall M (2014) Do science parks promote research and technology? A scientometric analysis of the UK. Scientometrics 102:701-725. doi:10.1007/s11192-014-1435-Z

Mirkin B (2010) Population levels, trends and policies in the Arab region: challenges and opportunities. United Nations Development Programme. Regional Bureau for Arab States, New York

Miro O, Montori E, Ramos X, Galicia M, Nogue S (2009) Trends in research activity in toxicology and by toxicologists in seven European countries. Toxicol Lett 189:1-4. doi:10.1016/j.toxlet. 2009.04.029

Nature (2015) Developing partnerships. Nature 527:S60-S63. doi:10. 1038/527S60a

Nawar SS, Doma HS (1989) Removal of dyes from effluents using low-cost agricultural by-products. Sci Total Environ 79:271-279. doi:10.1016/0048-9697(89)90342-2

Nriagu J (2008) The first 36 years of Science of the Total Environment (STOTEN). Sci Total Environ 400:2-5. doi:10. 1016/j.scitotenv.2008.07.007

Ntuli H, Inglesi-Lotz R, Chang T, Pouris A (2015) Does research output cause economic growth or vice versa? Evidence from 34 OECD countries. J Assoc Inf Sci Technol 66:1709-1716. doi:10. 1002/asi.23285

Onsman A (2010) Dismantling the perceived barriers to the implementation of national higher education accreditation guidelines in the kingdom of Saudi Arabia. J High Educ Policy Manag 32:511-519. doi:10.1080/1360080x.2010.511123

Padmanaban VC, Giri Nandagopal MS, Madhangi Priyadharshini G, Maheswari N, Janani Sree G, Selvaraju N (2016) Advanced approach for degradation of recalcitrant by nanophotocatalysis using nanocomposites and their future perspectives. Int $\mathrm{J}$ Environ Sci Technol 13:1591-1606. doi:10.1007/s13762-0161000-9

Plucknett DL, Smith NJ (1984) Networking in international agricultural research. Science 225:989-993. doi:10.1126/science.225. 4666.989

Qadir M, Oster JD (2004) Crop and irrigation management strategies for saline-sodic soils and waters aimed at environmentally sustainable agriculture. Sci Total Environ 323:1-19. doi:10. 1016/j.scitotenv.2003.10.012

Rocher V, Azimi S, Moilleron R, Chebbo G (2004) Hydrocarbons and heavy metals in the different sewer deposits in the 'Le Marais' catchment (Paris, France): stocks, distributions and origins. Sci Total Environ 323:107-122. doi:10.1016/j.scitotenv.2003.10.010

Romeo M, Siau Y, Sidoumou Z, Gnassia-Barelli M (1999) Heavy metal distribution in different fish species from the Mauritania coast. Sci Total Environ 232:169-175. doi:10.1016/S00489697(99)00099-6

SCImago (2016) SJR-SCImago journal and country rank. http:// www.scimagojr.com. Accessed 4 May 2016

Shakeri A, Shakeri R, Mehrabi B (2015) Potentially toxic elements and persistent organic pollutants in water and fish at Shahid Rajaei Dam, north of Iran. Int J Environ Sci Technol 12:2201-2212. doi:10.1007/s13762-015-0754-9

Shanbhag VK (2016) Journal impact factor. Biomed J 39:225. doi:10. 1016/j.bj.2015.12.001

Shin JC, Lee SJ, Kim Y (2011) Knowledge-based innovation and collaboration: a triple-helix approach in Saudi Arabia. Scientometrics 90:311-326. doi:10.1007/s11192-011-0518-3
Simmons MR (2006) Twilight in the desert: the coming Saudi oil shock and the world economy. Wiley, New York

SJR (2016) SCImago Journal and Country Rank. http://www. scimagojr.com/. Accessed 22 May 2016

Sowers J (2013) Environmental politics in Egypt: activists, experts and the state. Routledge Studies in Middle Eastern Politics, vol 50. Routledge, London

Sweileh WM, Zyoud SH, Al-Jabi SW, Sawalha AF (2014) Bibliometric analysis of diabetes mellitus research output from Middle Eastern Arab countries during the period (1996-2012). Scientometrics 101:819-832. doi:10.1007/s11192-014-1361-0

Sweileh WM, Al-Jabi SW, Abuzanat A, Sawalha AF, AbuTaha AS, Ghanim MA, Zyoud SH (2015) Assessment of research productivity of Arab countries in the field of infectious diseases using Web of Science database. Infect Dis Poverty 4:2. doi:10.1186/ 2049-9957-4-2

The World Bank (2010) World development report 2010: development and climate change. Accessed 30 Sept 2016

Tolba M, Saab N (2009) Impact of climate change on Arab countries. http://www.afedonline.org/afedreport09/Full\%20English\% 20Report.pdf. Accessed 30 Sept 2016

Toope SJ, Tan CC, Fedoroff NV (2012) Science in Asia. Improving Asia-Pacific science collaboration. Science 336:38-39. doi:10. 1126/science. 1208378

UNESCO Institute for Statistics (2005) What do bibliometric indicators tell us about world scientific output? Basic Sci Technol Stat 2:1-6

van Raan AF (2005) For your citations only? Hot topics in bibliometric analysis. Measurement 3:50-62

Verner D (2012) Adaptation to a changing climate in the Arab countries: a case for adaptation governance and leadership in building climate resilience. World Bank, Washington, DC

Waast R, Rossi PL (2010) Scientific production in Arab countries: a bibliometric perspective. Sci Technol Soc 15:339-370. doi:10. 1177/097172181001500207

Wallin JA (2005) Bibliometric methods: pitfalls and possibilities. Basic Clin Pharmacol Toxicol 97:261-275. doi:10.1111/j.17427843.2005.pto_139.x

World Bank (2001) Making sustainable commitments: an environment strategy for the World Bank http://siteresources.worldbank. org/ENVIRONMENT/Resources/244380-1250028593656/ 6382907-1252510780845/6428643-1255012678534/WBGEnvironment-Strategy-2001-Full.pdf. Accessed 30 Sept 2016

Yataganbaba A, Kurtbaş İ (2016) A scientific approach with bibliometric analysis related to brick and tile drying: a review. Renew Sustain Energy Rev 59:206-224. doi:10.1016/j.rser.2015. 12.357

Yeatts KB et al (2012) Conducting environmental health research in the Arabian Middle East: lessons learned and opportunities. Environ Health Perspect 120:632-636. doi:10.1289/ehp.1104031

Zyoud SH, Fuchs-Hanusch D (2016) Estimates of Arab world research productivity associated with desalination: a bibliometric analysis. IDA J Desalin Water Reuse 7:3-16. doi:10.1179/ 2051645215y.0000000001

Zyoud SH, Al-Jabi SW, Sweileh WM, Awang R (2014) Assessing the scientific research productivity of a leading toxicology journal: a case study of human \& experimental toxicology from 2003 to 2012. SAGE Open Med 2:2050312114523424. doi:10.1177/ 2050312114523424

Zyoud SH, Al-Jabi SW, Sweileh WM (2015a) Scientific publications from Arab world in leading journals of Integrative and Complementary Medicine: a bibliometric analysis. BMC Complement Altern Med 15:308. doi:10.1186/s12906-015-0840-z

Zyoud SH, Al-Jabi SW, Sweileh WM, Al-Khalil S, Zyoud SH, Sawalha AF, Awang R (2015b) The Arab world's contribution to 
solid waste literature: a bibliometric analysis. J Occup Med Toxicol 10:35. doi:10.1186/s12995-015-0078-1

Zyoud SH, Al-Jabi SW, Sweileh WM, Awang R (2016a) Contribution of Arab countries to pharmaceutical wastewater literature: a bibliometric and comparative analysis of research output. Ann Occup Environ Med 28:28. doi:10.1186/s40557-016-0117-0
Zyoud SH, Al-Rawajfeh AE, Shaheen HQ, Fuchs-Hanusch D (2016b) Benchmarking the scientific output of industrial wastewater research in Arab world by utilizing bibliometric techniques. Environ Sci Pollut Res Int 23:10288-10300. doi:10.1007/ s11356-016-6434-6 